\title{
Revisiting aspects of entrepreneurship, entrepreneurial orientation, entrepreneurial intentions, international entrepreneurship, and their corresponding consequences
}

\section{Hamid Etemad ${ }^{1}$}

Published online: 29 October 2021

(c) The Author(s), under exclusive licence to Springer Science+Business Media, LLC, part of Springer Nature 2021

\section{Introduction}

It is nearly a public knowledge that entrepreneurship is s a potent vehicle for creating value-adding activities, locally and internationally, which create employment, growth, taxes and incremental wealth (Koellinger and Thurik 2012; Van Praag and Versloot). Many mission-oriented governments (Mazzucato 2013), ranging from local to national in emerging regions to highly advanced, have enacted policies (Brander et al. 2015) encourage further local entrepreneurship. The general expectation is that such polices stimulate entrepreneurship of various forms, and they will bear fruits soon to help resolve many socio-economic problems (Baughn and Neupert (2003); but not all entrepreneurial initiatives are equally productive or efficiently run. Theoretically, given conducive conditions, those aspirational government policies, and their corresponding stimulative incentives, hold the potential of bearing bumper crops and delivering results, some of which reach much beyond expectations; but a few do not (Baughn and Neupert 2003), and at times their enterprise will have to migrate to more conducive regions with more appealing environmental conditions to survive and grow. Consider, for example, that very few regions, such the California's region located between San Francisco and San Jose cities (popularly known as the Silicon Valley), New York City, amongst a few other regions in the United States, or Untied Kingdom, and Germany, among others, have attracted, and still do attract, high number of entrepreneurial start-ups with high growth aspirations and potentials that they do mostly attain, while others have relocated elsewhere in need of higher support. The theoretical question is: what accounts for some entrepreneurial start-ups accomplishing and sustaining their high growth rates; while others do not. Are they due to the initial entrepreneurial orientations (EO) (Covin and Lumpkin 2011), and entrepreneurial intentions (EI) (Moriano et al. 2012) or

Hamid Etemad

hamid.etemad@mcgill.ca

1 McGill University, Montreal, Canada 
other factors that would influence or intervene over time? The Route 128 areas of Boston, Massachusetts, was highly attractive to high-technology start-up from late 1970s to early 2000; but the high rates have not kept-up with other areas. It appears that some emerging environmental and institutional conditions have turned, and become comparative dis-incentives, if not barriers, leading to lower start-ups and even their migration to other regions (Moriano et al. 2012). Migrants would generally look for gaining faster and higher competitive advantage for higher growth earlier. Porter (1990) pointed to conducive factors at the national level with positive impact on firms and on start-ups in nationally competitive regions (Porter 1990). In contrast, Florida (2004) pointed to creative class, including entrepreneurs, would be attracted to locations with high amenities complementing relatively competitive resources. Although the definitive answers are not yet clear, a few factors have already emerged, including: i) Location (e.g., Attractive location with high amenities, rich socio-cultural resources, and attractive living conditions), ii) Strong support systems (e.g., Rich entrepreneurial eco-systems (Etzkowitz et al. 2000) offering the required support, including human resources), iii) Presence of high financial incentive (e.g., Low to now taxes for start-ups), iv) Conducive legal and institutional frameworks, and v) Some industrial specialization (e.g., industrial clusters and supper clusters) and vi) Certain institutional structures capable of assisting and expediting start-ups' growth and ensuring their survival. ${ }^{1}$ Growth-oriented entrepreneurship at the basic levels may involve creating embryonic firms that lack much of invested heritage (Etemad 2018) in terms of past experience, R\&D investments, proven business model and established track records (e.g., recognized brand(s) brand equity, etc.), necessary resources, and collaborative network of suppliers and buyers, among other requisites of growth, beyond self-employment. Stated differently, embryonic start-ups are like newly-born children, who need a high extent of substantive parental care, investment and support before reaching independence and success; the good intentions alone, even financial incentives to assist parental supports may not suffice (Bird 2015, Boso et al. 2017, Liñan and Fayolle 2015).

In contrast to stimulating local start-ups, entrepreneurial internationalization of relatively established local firms through potent strategies, such as Born Globals (Knight and Cavusgil 2004), (McDougall and Oviatt 2000) and Rapidly Internationalizing Enterprises (RIEs) (Etemad and Wu 2013; Keen and Etemad 2011 and 2013) can not only avoid the initial difficulties of starting-up in a location at home; they can also take advantages of the well established international marketing infra-structure and using intermediate entry strategies involving different forms of partnership with others (especially local firms) for entering into much larger international

\footnotetext{
1 These observations are in part based on personal experience and research in cities of Boston, Montreal and San Francisco. For example, the city of Montreal has become highly attractive to start-ups and established firms in Aeronautics (e.g., Airplane design and manufacturing due to a rich support eco-system for the industry, making the industry a major civilian airplane manufacturing supported by the government, universities and financial sectors), Artificial Intelligence (i.e., the city is recognized as one of the top 10 cities in the world for AI), Digital Gaming Platforms and Games (The city in a pioneering and major location for Digital Gaming), and Creative Arts. The city, provincial, and Federal governments have created incentive for the formation of "Super Clusters" in the above-mentioned sectors.
} 
markets. Generally, the supportive national infra-structure (Etemad and Motaghi 2018) assists SMEs' entrepreneurial internationalization. Such well-established and functioning infra-structures can link and propel smaller local firms with potential markets through partners who are resourceful and can assist them by providing the initially necessary arrangements in foreign country markets before strat-ups can create their own. ${ }^{2}$ Regardless of the international location for incremental entrepreneurial efforts to attain higher overall growth, some measure of competitiveness (local competitiveness for local embryonic start-up and global competitiveness for international markets ${ }^{3}$ ) is necessary to ensure effective and successful efforts. Theoretically, both of the above options (initial growth at home and early entry into international markets) hold the promise of generating incremental growth, income and wealth. However, and as briefly discussed above, some complicating personal and environmental factors may act as obstacles in achieving growth; and a number of such contemporary barriers are discussed below to set the stage for the other parts of this article.

The first and primary disturbing factor is the recent emergence of the Noble Corona Virus that first appeared in Wuhan, the capital city of the Chinese Province of Hubei, in late 2019, which the World Health Organization (WHO) called it as COVID-19 for short without pointing to its extremely high transmissibility and virality. That short form has not only become a part of our frequent daily parlance; but it is also referring to a global crisis with highly negative impact. On March 11th, 2020, WHO declared COVID-19 as a global pandemic and in less than two months, the virus infected country-after-country at a very high speed and without exception (Etemad 2021). The COVID-19 created global health and economic crises never experienced before, which forced many governments, and other private and public institutions of the society to nearly abandon their previously normal policy actions and focus on preserving the health and survival of their citizens, both the regular and corporate ones, including the small and medium sized companies, which continued to suffer deeply from the earliest stages of the crisis. The complete lockdown of major metropolises (and partial in case of essential needs) practically paralyzed not only most entrepreneurs, entrepreneurial SMEs, but also their network of buyers and suppliers as a whole, which brought most domestic, and especially international activities, to a near halt. It is only logical to assume that national and international economies, and their respective economic institution, also suffered to different extent, which dampened the intensity of economic activities world-wide. In short, the slowly emerging post-COVID-19 global environment, is likely to be very different from the pre-covid conditions. It may also take some time before economies return to a semblance of their pre-COVID-19 normalcy, which is a cause for concern, caution and questioning of the nascent start-ups' and aspiring SMEs' achieving their pre-COVID objective based on pre-COVID-19 assumption, environment,

\footnotetext{
${ }^{2}$ For example, the Canadian Embassies in major international markets have highly specialized marketing experts based in the Commercial Attaché Department of the Embassy that can provide detailed information and also solve Canadian SMEs' problems in their international location.

3 A firm's global competitiveness is the accepted international requisite for eventual success.
} 
policies and policy-actions. As discussed earlier, start-ups face difficult conditions under normal conditions, and the COVID-19 added further complexities that necessitate a further re-examination of prior assumptions, aspirations, and potentially stimulative strategies formulated for their corresponding prevailing Pre-COVID-19 conditions, both locally and internationally. Should the pre-COVID-19 premisses do not return in the short term (i.e., next two to three years), a critical re-examination of previously learnt experiences, strategies and policies, especially a re-formulation concerning entrepreneurship and new business start-ups, is called for. The above observation is based on extensive local lockdowns restricting normal routine arrangements and mobility of people leading to slow-down of economic activities for all enterprises and institutions, especially smaller and resource constrained enterprises then; thus making it more challenging for entrepreneurs to re-establish their local enterprises' activities to the pre-COVID Conditions. On the international fronts, the closure of borders, sever restriction of across-boarder mobility, which contributed to the near collapse of international supply chains and outsourcing by most enterprises, reduced the flow and the volume of international transactions, and made internationalization activities difficult, if not nearly infeasible. These occurrences rapidly created insurmountable challenges to smaller enterprises in general, and internationally oriented, or already internationalized, SMEs (iSMEs) in particular.

Furthermore, the near lockdowns and restrictions on mobilities contributed to, if not caused, the demise of countless already established smaller enterprises that were contributing members of a network of buyers and suppliers that supplied parts to networks, or relied on the networks' supply chain, which may not be able to resolve their difficulties and return to pre-COVID-19 operations soon. Consequently, alternative arrangements had to be made as quickly as possible. These occurrences suggest a need for the scholarly community to reflect on emerging changes in previous institutional arrangements and infra-structures and carefully examine what has changed and what new alternatives learned and utilized already. The casual evidence points to potentially adverse impacts on starting or re-starting economic activities, due to the considerable economic slow-downs, increased national budgetary deficits and higher national and global uncertainties with negative impacts on entrepreneurial start-ups, SMEs and internationalized SMEs (iSMEs, for short), to which we will return later-on. In Short, the prevailing environmental and institutional environments may have changed the pre-COVID-19 conditions and added to associated challenges for start-ups or SMEs attaining higher growth, regardless of whether they would be starting up at home or expanding internationally, which also calls for reflecting on the research findings based on the assumptions of past, and lessons of pre-COVID eras. Naturally, they may also apply to the scholarly articles completed before the COVID pandemic.

The second, but equally important, is the role of evolutionary change over time in the family of influential factors within their underlying environment, or entrepreneurial framework(s) in general, and those of international entrepreneurship (IE) in particular, during which the rate of change may have intensified in the COVID-19 period and may continue for sometimes. They also call for our scholarly attention and reflection as the change may have significantly 
altered their basic characteristics over time, some of which have been reactive but structural, and others have been evolutionary and policy-driven with stimulative objective to dampen the effects of the unusual conditions (Brander et al. (2015), including the COVID-19 pandemic, and the 2008-2009 global financial crisis, the 2000-2003 severe acute respiratory syndrome (SARS) epidemic, amongst others. Consider, for example, that their direct and perceived effects on the formation and evolution of entrepreneurial orientations (Covin and Lumpkin 2011) and corresponding entrepreneurial intentions (Schlaegel and Koenig 2014) due to exposure to successful family businesses and entrepreneurs at one extreme or exposure to entrepreneurial-oriented start-up struggling for survival at the other. Unexpected and unprecedented conditions may have pushed innovative entrepreneurs to unexpected successes (Etemad 2020), while forcing others to bankruptcy and eventual demise due to unusually rapid change (e.g., Early days of COVID-19) amongst other adverse forces. Such demises neither do fit well into the main characteristics of entrepreneurial orientation framework (e.g., Miller's (1983a and 1983b) innovativeness, proactiveness and risk tolerance framework) nor accord with the attributes of entrepreneurial intentions (e.g., based on Ajzen'(1988 and 1991), Krueger and Carsrud 1993, among others) Some of these acumulated changes were not observable, nor predictable, beforehand to allow entrepreneurs to examine them from their risk tolerance perspective (Knight 1929 and 1957, Grable 2000, Cramer et al. 2002, Stewart and Roth 2001), and may not quickly return to a steady-state status, which questions the time duration of pro-activeness and tolerance for bearing the higher magnitude of uncertainties ahead.

Aside from the uncertain future prospects, and the unclear challenges ahead, especially the evolutionary and structural changes may implicitly have affected the actual attributes and characteristics of the various underlying entrepreneurial frameworks already. Naturally, when such on-going changes have become a part of the prevailing state of affairs; but not incorporated by scholars in their respective research as the emerging change in the foundations of the theoretical and empirical research, their affects may have remained unaccounted-for. Consequently, their corresponding impacts on their international counterpart must be also reconsidered. As the above aspect may have broad implications on scholarly research, and their consequent findings, this article is addressing some of the potentially influential issues and will call for a broader re-examination by the scholarly community for their respective effects on our already learnt lessons and also the lessons of the on-going research that may appear shorly.

The structure of this article This article will consist of four parts. Following the above introduction, part II will present a theoretical re-examination of selective aspect of a few traditional entrepreneurial concepts and their international counterparts. Part III will present an examination of the four articles included in this issue next, from a confirmatory, expansive or critical perspectives, in order to shed further light on fundamental entrepreneurial concepts, such as entrepreneurial orientation (EO), entrepreneurial intentions (EI) and their consequent outcomes in light of the evolutionary, strategic and structural change (Miller and Friesen 1983) across 
their respective contexts and over time. A discussion and implication of the significant issues will follow in part IV, and the conclusion will be presented in Part V at the end.

\section{Further examination and developments}

There is a general consensus that entrepreneurship has become the engine of growth in many emerging and advanced economies and local government are expected to exploit its potential power. Aside from some 30 countries with relatively higher GNP per capita (based on PPP) at the time of this writing (September 2021) (Source: https://en.wikipedia.org/wiki/List_of_countries_by_GNI_(PPP)_per_capita), which already have relatively high entrepreneurial orientations, there are nearly 200 other countries, who are looking for a potent growth formula, or growth engine, to improve upon their population's well beings. Nearly every government has already introduced a list of policy instruments to encourage entrepreneurs to start-up companies, or attain higher growth by their mature companies by, for example, responding to unsatisfied needs, creating more innovative products and services, and localizing production and distributions (Veglio and Romanello 2021) of goods and services with high consumer perceived value (CPV) in order to enable them to produce locally, hire new local employees, create further income and wealth primarily at home. ${ }^{4}$ As discussed above, other intervening factors may stimulate, or adversely impact, the ultimate local results of such stimulative policies.

The internationalization of entrepreneurship can push the frontiers even further by taking a smaller company facing a limited market at home to international markets, which allows the company to grow through higher international sales (i.e., gain on scale economies), and more importantly, learn from the indigenous local companies to become as competitive, if not more competitive, as local firms in particular (i.e., To also gain economies of scope). Such internationalization can give them competitiveness in local foreign markets and consequently their higher global competitiveness can be further exploited elsewhere, including at home (Welch 1996 and Welch and Luostarinen 1988 and 1993). There is a full recognition that, if smaller entrepreneurial companies do not become globally competitive by, for example, taking advantage of economies of scale (due to increased scale), economies of scope (due to the diversity in different foreign local markets), their combined synergy, and possibly symbiotic relations (Etemad et al. 2008) to gain increased global competitiveness, globally competitive firms may invade the firm's local home markets and negate the impact local governments' stimulative policy actions. Stated differently, refraining from internationalization offers no long-term protection or strategic advantage, which raises the questions of, and relates to, local change and the changing evolutionary trends in the international counter parts of entrepreneurial

\footnotetext{
4 The recent research regarding post COVID strategies point strongly to the urge for localization of production and control to avoid future COVID-like disruptions in international production and distribution See Etemad 2022 (forthcoming).
} 
orientation and entrepreneurial intentions (Liñan and Fayolle 2015, Krueger and Carsrud 1993) due to increasing global competitiveness and international competition over time, as briefly discussed above. These evolutionary trends over-time, and other institutional, structural, and environmental changes may differentiate between the earlier and later states of various factors and their respective impact on their consequent outcomes. In short, the over-time comparative and location-specific (e.g., home and foreign local market) analyses need to reflect, and account for, the potential influences of various changes across locations and over time (e.g., from pre to post-COVID-19 environments).

On the other side of the ledger, the globalization of marketplace has enabled truly massive firms, such as Alibaba.com, Amazon.com, Shopify.com, Spotify.com, among many others, to compete globally through their digital on-line platforms, which transacts and delivers world-wide and at times to one's door-steps. Their scale and scope economies and institutional efficiencies allow them to literally respond to local needs and wants, and deliver higher CPVs, as if they were local, and compete effectively with not-so-competitive firms in their own home markets. Shopify.com, for example, competes through its network of nearly one million local affiliates in 175 country markets transacting in 133 different currencies (Source: http://www. shopify.com). The above observed evolutionary trends suggests that national governments' public policy actions are likely to be reacting to the adverse impacts of global competition in the post COVID-19 era and their policy incentives for increasing their national entrepreneurship may be less effective than expected.

The puzzling question before us, therefore, is: which (and why) certain local policies encouraging entrepreneurship are not effective; while similar socio-cultural and economic policies in other countries have led to comparatively successful entrepreneurship (Hayton, George, Zahra 2002). As stated above, stimulative entrepreneurial policy environment combined with a conducive and complimentary entrepreneurial ecosystem is necessary to result in at least partial, and possibly complete, success. Let's consider a very simple ecosystem (Etzkowitz et al. 2000), consisting of only four parts - i.e., a) the industry, b) the government, c) the universities and d) a collaborative network of buyers and suppliers (Mazzucato 2013, 2016 and 2018). Naturally, such a collaborative ecosystem needs to function well with synergy amongst all its components when they collectively cooperate, collaborate and create value to enable a firm, possibly a start-up, to grow as rapidly as possible and become as active globally to avoid globally competitive larger companies, such as MNEs, to adversely impact its growth and possibly invade its home market. As discussed earlier, the start-ups global competitiveness, despite their home's smaller economies of scale and scope, may avoid demise or loss of independence by a hostile take over or outright acquisition.

Following the earlier discussion, the global pandemic crisis made the environment at home or international markets less conducive and less enabling, if not more hostile, for SMEs and iSMEs. In countries like Canada, where more than $90 \%$ of firms are small, it added difficulty and complexity to the environment with adverse impact on the growth or internationalization of companies. In fact, restriction on mobility at home and abroad, combined with barriers to free movements of goods and services across international borders, created less conducive environmental 
conditions for small and medium sized enterprises. Similarly, COVID-19's global crisis also adversely impacted the various components of a country's ecosystem, including the basic four elements (Etzkowitz et al. 2000) (i.e., governments ran higher budget deficits, industries slowed-down, universities shut-down and collaborative network could not operate efficiently). Similarly, the complementary network of buyers and suppliers became less active, mainly because of global slow-down and partial lockdowns, locally and internationally.

We will briefly examine selective components of the eco-system. Consider, for example, that governments' deficits increased in order to help reducing the adverse impact of COVID-19 on peoples' deteriorating health, increasing cost of health care system, and higher unemployment, which combined with rapidly rising operating cost of the health care systems (e.g., due to over-crowding), all adding to the deficit, with adverse effects on governments' ability to implement their previous stimulative policy actions. More importantly, the COVID-19 crisis diverted the attention of the governments from following their own mission-oriented entrepreneurial policies designed to encourage more entrepreneurships. Population's health and well-being took over the center stage.

On the industry side, the mirror image of the above situation for potential entrepreneurs within an industry was equally bleak, if no disturbing, as the near lockeddown conditions did not provide friendly environment for either starting-up an embryonic firm, or for a small company, so that they could formulate potent strategies for further growth, locally and internationally, due to the prevailing and emerging massive uncertainties. Simply, neither the markets were as active, nor was the demand, as promising as in past due to lock-down, reduced mobility restrictions and increased risks and unemployment.

Regarding the third element of the eco-system, the research and development engines of the society, such as the universities, research and development institutions (including the national research and development laboratories and private or corporate innovative research laboratories) and other knowledge-creating agencies became much less active due to restrictions and slow-downs. In fact, in-person activities of many innovation, and knowledge-creation efforts, in the laboratories of the universities, shut down and the wheels of innovation nearly stopped. In general, the industry's innovative research and developments support the innovative and value-creating activities of entrepreneurial start-ups, and the COVID-19's adverse conditions paralyzed the synergic actions of the eco-systems (Etzkowitz et al. 2000). Finally, the intangible fourth element of that ecosystem, namely the complementary network of buyers, suppliers and complementors, including social, financial, and the general support system slowed down, and shut down in some cases. In short, the eco-system did not operate effectively.

In contrast, private venture capitalists looking for potential candidates to support financially in certain regions of the world, such a Silicone Valley, Route 128 in Massachusetts, New York City and Cambridge-Oxford corridors in the UK, amongst others, took advantage of the situation and became even more active as the slowed socio-economic conditions offered more time to start-ups to improve upon their business plans to accomplish their objectives without the time pressure, which would usually add to the costs and "burn-rates". The above brief review could be 
considered as the learned lessons complementing what the literature has already documented. In short, the various policy environments and the components of their prevailing ecosystem would need to work effectively, efficiently, and strategically as the underlying foundations in order to fully support the entrepreneurial initiatives to proceed successfully.

The main aim of this article was not to review or explore competitive ecosystems, or to point out the synergic conditions that underlie successful, productive, and effective within a synergistic framework. However, the consideration of eco-systems perspective is a simple, but powerful, concept that can help us to critically evaluate the underlying framework in scholarly research in light of change and newly emerging developments (Etzkowitz et al. 2000). Following the above discussion, the brief highlights of the four articles that follow will add much positive contributions of their authors and co authors armed with appropriate methodologies and theories for necessary updating of the evolutionary and structural change over-time; as well as the other environmental variations due to the global crises, including the local dysfunctional conditions that yield less fruitful entrepreneurship. In light of the above perspective, the brief highlighting of the four articles included in this issue are presented below before turning to discussions and examining of their collective implications in the conclusion.

\section{The brief highlights of the following four articles included in this issue}

The second article in this issue is entitled as "A dynamic relationship between entrepreneurial orientation and entrepreneurial activity" and is co-authored by Farzana Chowdhury and David B. Audretsch. This article raises the question of why entrepreneurial orientated activities vary across different countries, which in turn, raises the fundamental question of what is the dynamic relationship between entrepreneurship and its embedding environment in a given region, and how that dynamic influences entrepreneurial orientation (EO), the corresponding entrepreneurial intention (EI), and their consequent entrepreneurial activities? By a logical extension, one should also ask: what is, are or even should be, the dynamic influence(s) of national environmental factors on the counter parts of entrepreneurial orientation and intentions in a given international market in particular, and in the global context in general? In favovour of clarity, we call the international counter parts of entrepreneurial orientation and entrepreneurial intentions as international entrepreneurial orientations (iEO) and international entrepreneurial intentions ( $i E I)$, respectively.

The brief above discussion suggests that, if one finds, and reports, a significant and reliable relationship between personal factors (e.g., Education, experience, social capital, risk tolerance, wealth, etc.), environmental factors (e.g., Institutional and legal structures and socio-economic evolutions, etc.) and locational, or geographic factors (e.g., Universities in different countries) ${ }^{5}$ affecting one's EO at one

\footnotetext{
5 These factors are discussed in some depth in the articles that follow.
} 
time period (i.e., $\mathrm{EO}_{\mathbf{t} 1}$ ), then the dynamics of evolutionary and structural change over time should result in a somewhat different EO at a different time period (i.e., $\mathrm{EO}_{\mathbf{t} 2)}$. The difference between the two $\left[\left(\mathbf{E} \mathbf{O}_{\mathbf{t} 2}\right)-\left(\mathbf{E} \mathbf{O}_{\mathbf{t} 1}\right)\right]$ (and similarly their international counterparts $\left.\left[\left(\mathbf{i E O}_{\mathbf{t} 2}\right)-\left(\mathbf{i E O}_{\mathbf{t} 1}\right)\right]\right)$ should, therefore, be attributed to the differential change of the evolutionary institutional and institutional influences over time. Logically and given different embedding environments in different countries, one should also expect different corresponding levels of EOs in different markets, which would form a distribution of iEOs in international markets as a whole and evolving over time. Naturally, should such distribution exist, it points to different EO or $\mathrm{iEO}$ across nations and over time providing a perspective on questions raised by this article.

Based on path dependence (David (2001) and Imprinting Theory (Marquis and Tilcsik 2013), the authors both support the above discussions, and suggest that historical events, and change in circumstances overtime, can influence the structure of institutions and environment (Stenholm et al. 2013), which in turn, may influence personal factors and associated entrepreneurial orientation (Vergne and Durand 2010). Such personal and environmental changes over time, are likely to influence the trend and trajectory of entrepreneurial orientation, entrepreneurial intentions, and their subsequent entrepreneurial activities and consequent results.

The two inquisitive research questions that lead to the research were: i) How do individual's past experience within one's home country institutions influence one's EO and differ in a changing institutional environment in another country (Stenholm et al. 2013) - e.g., an emerging market versus advanced country environments and ii) How does such change in individual's resources influence one's EO in the context of changing institutional environment in an emerging and evolving country. Carrying out an extensive literature review, the authors' formulated propositions suggesting that individuals do respond to institutional and structural changes in their environments. Similarly, one's evolving lifetime experience is likely to influence the various components of one's EO over time - i.e., one's innovativeness, proactiveness, and risk-taking, or risk-bearing (Grable 2000 and Herranz et al. 2015) - and consequently result in one's evolving entrepreneurial orientation. Consider for example that, when one has been experiencing continued successes (in terms of education, personal and professional endeavours, resulting in increasing income and wealth), which could influence one's evolving perspective and the individual's entrepreneurship orientation because of one's increasing capacity to afford larger losses, or tolerate higher risks, especially in emerging country, where resources are not in abundance as compared to richer industrialized and developed countries, where perceived risks are generally higher. In contrast, the entrepreneurial orientations and intensions are likely to decline when entrepreneurs experience string of loses of income and wealth over time. It is, therefore, logical to observe different entrepreneurial orientations and intentions across countries and evolving environments over time (Bird 2015) as proposed by the second article.

The third article in this issue is entitled "Personal factors, entrepreneurial intention, and entrepreneurial status: A multinational study in three institutional environments" and is co-authored by Christopher Schlaegel, Robert L. Engle, Nicole Franziska Richter and Pia Christin Taureck. This article picks up where the second article 
left-off and the two articles relate to one-another as if they were parts of a broad research program. The main research question prompting this program of research was a deeper understanding that affects all personal factors and entrepreneurial outcomes in different institutional contexts. Relating to the previous article's propositions, the underlying research of this article examined a broad and comprehensive list of personal factors with potential influence on entrepreneurial outcomes. Viewing the research broadly, this article's research is an exploration of person-entrepreneurship fit theory (Markman and Baron 2003; Riedo et al. 2019). The first part of study used relatively large sample of students in Germany (255), Russia (224) and United States (286) and the list of factors with potential impact on entrepreneurial orientation (EO) and entrepreneurial intentions (EI), including variables selected from: a) A broad list of personality traits (i.e., openness, extraversion, emotional instability, and consciousness), b) From narrow traits (i.e., risk taking propensity, innovativeness on proactiveness, which are the traditional concept in EO), and c) From personal capabilities (i.e., the emotional intelligence).

The second part of the study used a sample of entrepreneurs and non-entrepreneurs (employees) respectively in Germany (100 and 118), Russia (67 and 91) and the United States (71 and 88). The research team found that the comprehensive list of variables (i.e., from the broad personality traits, narrow traits, and personal capabilities) had impacts on EI and EO (called the entrepreneurial status) in at least one country. Furthermore, each component of EO had significant impact on the entrepreneurial aspects of their international sample of entrepreneurial status of their samples of entrepreneurs and employees.

In short, this comprehensive study of student in educational context in the first part, and the comparative analysis of the entrepreneurs and employees embedded in the three country environments in the second parts of the study, provide support for the person-entrepreneur fit theory in the first and entrepreneurial intentions and orientation in the second part of the study in three distinctively different country environments (i.e., Germany, Russia and United States). Overall, this study supports our above theoretical arguments in support of the second article (above) regarding the relationship between $\mathrm{iEO}, \mathrm{iEI}$ and entrepreneurial activities, as well as the effect of their corresponding embedding environment on their corresponding EO and EI on the one hand, and their international counterparts (i.e., and international entrepreneurial outcomes) on the other hand.

As the title indicates, the fourth article in this issue is entitled as "Entrepreneurial intention: An analysis of the role of student-led entrepreneurial organizations" and is co-authored by Giuliano Sansone, Elisa Ughetto and Paolo Landoni. This article complements and provides further support for the theoretical propositions of the second article and the further elaboration regarding why we should expect, and empirically observe, differing EO and EI in different embedding environments with different evolutionary trends in emerging economies and across time. This article expands on a narrow and specific aspects of the above discussions by exploring the role and influence of training students in student-lead entrepreneurial organizations (SLEO) on their subsequent EO, EI and consequent entrepreneurial activities. It found empirical support for the positive influence of training, personal interest and involvements in SLEOs in raising EO and EI, which should be viewed as 
a significant importance to emerging environments encountering low EO, EI and entrepreneurial activities.

The observation and subsequent research leading to this article's empirical findings was the response to the question of whether student' higher interests and involvement in entrepreneurial activities of SLEOs, such as junior Enterprise Europe (JEE), would result in their higher entrepreneurial intentions due to their spending time in, and experientially leaning in JEEs, which are influencing, if not shaping and fostering, students' experiential knowledge and capabilities. This research was conducted broadly and found that students' prior capabilities, such a fluency in more languages and specializations in science and technology, would positively contribute to higher EO and EI. In light of the second article's discussion of EO, especially for students in the emerging economies as potential future entrepreneurs, the significant implication of this research is the importance of introducing experiential entrepreneurship and engaging in-stream students through SLEOs education and training to foster stronger EO and EI. Naturally, further hands-on involvements can solidify students' intentions in further pursuing entrepreneurship.

The fifth article in this issue is entitled as "Entrepreneurial intention among online and face-to-face university students: The influence of structural and cognitive social capital dimensions" and is co-authored by Noemí Pérez-Macías, José-Luis Fernández-Fernández and Antonio Rúa-Vieites. This article extends the above arguments and further integrates aspects of social capital from two different, but complementary, perspectives with the above research. Using Ajzen's theory of planned behaviour (1988 and 1991), it attempted to explore the potentially differentiating impact of structural and cognitive social capital through network ties, common language and common vision on the one hand, and in two different embedding contexts - i.e., undergraduate university students' on-line (302 students) and in-person (204 students) - in terms of their potential impacts on entrepreneurial intentions on the other. The papers' incisive methodology suggested a non-significant difference between the on-line and the in-person students. However, social capital had a higher and significant effect on the on-line group of students than the in-person student group.

In summary, the above five articles make a significant contribution to entrepreneurship, and by a logical extension to international entrepreneurship, by exploring different influences on iEO, iEI and entrepreneurial outcome from different perspective, including the differentiating impacts of change in contextual, evolutionary and structural factors (e.g., through social capital) on the traditional concepts of EO, AI, entrepreneurial outcomes and their international counter parts across nations, interest and involvement as well as experiential training over-time.

\section{Discussion and implications}

This discussion further expands on the above highlights and significant arguments presented earlier in order to explore their implications covering four aspects of entrepreneurial orientations, intentions and consequent activities in four parts, including: i) Variations in EO and Entrepreneurial Outcomes in Emerging Economies, ii) 
Raising the Innovative Dimension of EO, iii) Encouraging and Stimulating Proactiveness, and iv) Continued Early Assistance, Coordination, Integration and Stimulations; each of which are briefly discussed below.

i) Variations in EO and Entrepreneurial Outcome in Emerging Economies. As reviewed earlier, entrepreneurship has become a popular policy for achieving higher growth, especially in emerging markets that aspire to grow faster than before and others; but entrepreneurship has not resulted in outcomes similar to those in more entrepreneurially oriented areas, such as California's San Francisco-San Jose Area (Silicon Valley), Boston's Route 128 Areas, UK's Oxford University and Cambridge University areas, which raises the question of what would account for the discrepancy?

Start-ups, relatively smaller, and weaker local companies have faced higher challenges at home and also in entering international markets for taking advantage of international markets' larger size to offer them scale economies and diversification. As discussed earlier (in the Introduction), different embedding environments, and undergoing relatively rapid change, require and even impose, change in strategy (Miller and Friesen 1983) to gain added competitiveness for operating in international markets, without which growth at home and abroad would be difficult. Logically, the desire to gain higher competitiveness through higher innovations, risk-taking and timeliness (or proactiveness) of EO's motivating forces and entrepreneurial intentions to attain higher global competitiveness for competing globally.

The option of refraining from entering international markets to avoid re-strategizing offers no protective defence to firms staying at home. Globally competitive firms can enter and easily invade local markets of the less competitive players, which suggests that both the local governments and smaller firms need to formulate strategies for enhancing, and increasing, competitiveness of nascent start-ups and possibly protecting them for a limited time period while they remain vulnerable.

There is a general consensus that entrepreneurship can become an engine of growth, job, income and wealth creation in additional to social contributions when entrepreneurship is embedded (Granovetter 1985) within and supported by a conducive environment, or operates within a consistent, productive, and strategic framework, which can enable entrepreneurs to start up with a smaller initiative successfully and grow it to a globally competitive one eventually. The question is, therefore, what should be, or what constitutes, a conducive entrepreneurial framework to encourage and stimulate entrepreneurship, especially in emerging economies that aspire to grow faster?

The literature review of the second article in this issue suggested that significant historical events may have potentially influenced a region's structural, institutional, and evolutional trajectories with corresponding impacts on entrepreneurial orientations and consequent outcomes. In turn, their embeddedness (Granovetter 1985) in a changing environment may have affected entrepreneurs' social network, social capital (Ashourizadeh \& Schott 2016), and relationship with other components of their eco-system, including relations with the government, industry, and the society as a whole to avoid slow downs in achieving respective entrepreneurial outcomes. As 
a complementary example, consider the case of mature serial entrepreneurs experiencing successes (Krueger 1993), where their effective problem-solving capabilities, even in turbulent environment, could avoid crises, especially at the embryonic stages of the start-up - that would frequently results in the start-ups' demise, which contributes to further raising their confidence, increasing their EO, and strengthening their entrepreneurial intentions (EI) after a string of successful experiences; as opposed to negative entrepreneurial experiences. It is logical to suggest that, past successes are bond to affect the entrepreneurs' next entrepreneurial attempt with successful outcomes. Generally, maturing serial entrepreneurs, who have gained increasing experience as they had learned over time as how to encounter difficulties, and for example, resolve uncertainty of different kinds (Akerlof 1970 and Knight 1929/1957), the economic, socio-cultural, legal, and even institutional change, and other challenges. On the opposite side, entrepreneurs who had encountered crises in their earlier attempts may have developed a higher perception of risk, which could nearly lead to shying away from even mildly risky entrepreneurial activities. Combined, age, experience, perception of the current uncertainties and the projection of the future trends are theoretically bond to impact entrepreneurial orientations' trajectory overtime. Naturally, the evolutionary trends in different geographical regions are also likely to yield different entrepreneurial orientations and correspondingly different entrepreneurial experiences, orientations, intentions, and consequent outcomes.

In light of the above discussion of EO, and factors influencing it, the significant implications of this and other complementary research, is a need for reducing the perceived risk components of entrepreneurial orientation, regardless of location and time periods. As discussed earlier, the presence of conducive, stable, and entrepreneurially oriented environments to strengthen potential entrepreneurs' EO to start entrepreneurial activities so that they would not be worrying about the additional risks associated with rapid institutional, structural and evolving change adding to their perceived risks and uncertainties that further de-stabilize the state of their entrepreneurial activities at the time. Avoiding such stabilizing conditions are within the powers of the governments and could contribute to higher entrepreneurial activities, especially in the emerging economies.

ii) Raising the Innovative Dimension of $\mathrm{EO}$. The passion for creating something new or be innovative is a highly critical aspect of EO, without which the new start-up would be exposed to competition and possibly paralyzed by it. Innovation and innovativeness relate to an innate human creativity that can be also learned and enhanced by training and education. Most university graduates from sciences, technology, education and mathematical (STEM) disciplines are trained to become creative or further enhance their respective creativities. However, most STEM graduates lack entrepreneurial orientation to exploit their own innovativeness or pursue potential opportunities for enhancing, or even re-creating, other innovations for successful commercialization through an entrepreneurial start-up. The implication of this aspect is to expose STEM graduates to entrepreneurial activities and training in order to enable them to exploit innovations of their own and others at the outset by relying on their learnt lessons for continued 
and increased innovativeness over time. As discussed in the fourth article in this issue, STEM students can be introduced to, and get involved-in, entrepreneurial activities of, for example, student-led entrepreneurial organizations (SLOEs) to further develop their own innovations and creativity or to help to enhance others' creative activities. The clear implication of this discussion is three folds: a) To introduce in-stream STEM students to entrepreneurship courses, internship, and other forms of entrepreneurial training; b) To provide in-stream entrepreneurial students to similar exposures to STEM discipline and follow-up training; and c) Set-up student- or professional-led entrepreneurial organizations to enhance complementary exposure to, and interactions with others' innovativeness and risk taking to reduce shying away otherwise. Furthermore, the cooperation and interactions of the in-stream entrepreneurship students and STEM students are likely to result in higher combined efficiencies, regardless of the institutional arrangements, which is an incentive for facilitating such arrangements.

iii) Encouraging and Stimulating Proactiveness. As a significant component of EO, proactiveness is critical to success in start-ups' commercialization. Timeliness is also critical to creativity, innovation, and innovativeness, as time grants priority to earlier introduction and commercialization of new products and services. Later introduced innovations are likely to be viewed as copycats even though they offer additional new features. At least two factors can stimulate and expedite pro-activeness, including: a) Characterizing risk dimensions of the entrepreneurial activity in expediting all related (and specially time-consuming) activities to reduce the likelihood of falling behind the introduction of similar goods and services by others; and b) To help resolve all impediments of earlier commercialization; both of which can be enhanced by governmental direct assistance (e.g., subsidized venture capital institutions) (Lazzarini SG 2015) through, for example, start-up Accelerators and Incubators, amongst other similar organizations.

iv Continued Early Assistance, Coordination, Integration and Stimulations. As stated earlier, embryonic start-ups can be viewed as new-borns in need of parental attention and care before they can gain the confidence of operating independently. Such attention and care need to extend beyond early entrepreneurially oriented education and training stages and continue through-out challenging activities, such as coordination with suppliers, service providers, and major customers earlier on. Naturally, un-intruding mentorship can also help to integrate seemingly unrelated functions and stimulate the efficiency of early operations to avoid unexpected damaging occurrences. The guidance of highly experienced and interested mentors, such as retired successful executives, can be invaluable.

In summary, the above discussions and their corresponding implications are based on the early theoretical and empirical research contained in this issue and the much in-depth supportive argument are found in the related above articles, amongst others. 


\section{Conclusion}

This brief conclusion returns to the theme of this article regarding aspects of entrepreneurial orientation, intentions and consequent activities and outcomes at firms' home-base initially, and in international market eventually later-on. The increasingly popular policy of entrepreneurship, as the engine of value creation, and generation of growth through raising employment, income, and wealth, especially in emerging economies, is well a conceived public policy based on theoretical and strategic structures. However, and similar to any solidly built structure, entrepreneurship needs a solid foundation underlying and supporting the entrepreneurial structure and activities to enable them to grow an bear fruits in the due course of time. Earlieron, this article used the concept of embedding environment, or conducive infrastructure, ideally immune to adverse forces, so that it would be highly protective and supportive of entrepreneurial activities and their consequent positive outcomes, at least in the earlier stages. Logically, entrepreneurs would like to benefit from a solidly built and already installed entrepreneurial supportive foundations, on which they can build their own entrepreneurial structure, which could withstand opposing, and possibly destructive, forces. Whether such strong and supportive foundations can be easily created or not, it is implicitly assumed to exist and function well, especially for protecting embryonic start-ups in emerging markets, which need to improve upon their respective economic, institutional and socio-cultural structures. Should the early-stage construction of such improvement give rise to instability and de-stabilizing change, entrepreneurially orientations, intentions, subsequent activities and outcome will suffer. Therefore, ensuring stability in a conducive and highly protective environment to support entrepreneurial activities, especially in earlystage start-up, is an indispensable necessary condition preceding the enactment of a conducive entrepreneurial policy. Scholars are invited to further peruse related theoretical and empirical research related to the above arguments of this conclusion.

Returning to the earlier arguments that contextual change in the embedding environment or the supporting theoretical framework may have not been accounted-for in our collective scholarly research, this article addressed some aspects of them earlier in the development section and examined some of their potentially influential issues throughout this article. Finally, the journal calls for a broader re-examination of the above issues by the scholarly community for their respective effects on our collectively learnt lessons.

\section{References}

Ajzen I (1988) Attitudes, personality, and behavior. Open University Press, Milton Keynes Ajzen I (1991) The theory of planned behavior. Organ Behav Hum Decis Process 50(2):179-211

Akerlof GA (1970) The market for "lemons"': quality uncertainty and the market mechanism. Q J Econ $84: 488-500$

Ashourizadeh S, Schott T (2016) Exporting embedded in culture and transnational networks around entrepreneurs: a global study. International Journal of Business and Globalisation 16(3):314-325 
Baughn CC, Neupert KE (2003) Culture and national conditions facilitating entrepreneurial start-ups. J Int Entrep 1:313-330

Bird B (2015) Entrepreneurial intentions research: a review and outlook. Int Rev Entrep 13:143-168

Boso N, Oghazi P, Hultman M (2017) International entrepreneurial orientation and regional expansion. Entrep Reg Develop 29:4-26

Brander JA, Du Q, Hellmann T (2015) The effects of government-sponsored venture capital: international evidence. Rev of Fin 19(2):571-618

Covin JG, Lumpkin GT (2011) Entrepreneurial orientation theory and research: reflections on a needed construct. Entrep Theory Pract 35:855-872

Cramer J, Hartog J, Jonker N, Van Praag C (2002) Low risk aversion encourages the choice of entrepreneurship: an empirical test of a truism. J Econ Behav Organ 48:29-38

Dana LP, Wright R (2008) Towards a Paradigm of Symbiotic Entrepreneurship". Int J Entrep Small Bus V5(2):109-126

David PA (2001) Path dependence, its critics and the quest for 'historical economics'. In: Garrouste, Pierre/ Stavros Ioannides (eds.), Evolution and path dependence in economic ideas: past and present. Cheltenham: Edward Elgar, 15-41

Etemad H (2020) Extending international entrepreneurship's concepts, constructs and decision frameworks to reach beyond the ordinary. J Int Entrep V18(3):257-269. https://doi.org/10.1007/ s10843-020-00283-3

Etemad H, Motaghi H (2018) Internationalization pattern of creative-cultural events: Two cases from Canada. Int Bus Rev 27(5):1033-1044. https://doi.org/10.1016/j.ibusrev.2018.03.003

Etemad H, Wu Pi-C (2013) Revisiting Aspects of Born Globals: Young Canadian SMEs Growing Rapidly and Becoming Born Globals" in Etemad, H. (ed), Current Issues in International Entrepreneurship, Edward Elgar Publishing Ltd., Northampton, Mass. and Cheltenham, UK, Nov/Dec. 2013, PP. $13-37$

Etemad H, Wright R, Dana LP (2001) Business Networks: Collaboration Between Small and Large firm. Thunderbird International Business Review, V. 43, No. 4, (July-August 2001), PP. 481-500

Etemad, H., (2018), Early strategic heritage: The carryover effect on entrepreneurial firm's life cycle" Journal of International Entrepreneurship (JIEn), V16, No. 4 (Fall 2018), pp. 441-455, https://doi. org/10.1007/s10843-018-0240-9. https://link.springer.com/content/pdf/10.1007\%2Fs10843-0180240-9.pdf

Etemad H (2021) (Ed.) Small and Medium Sized Enterprises and their COVID-19 Response: Global Perspectives on Entrepreneurial Crisis Management, Edward Elgar Publishing, Northampton, Mass. 2021 (Forthcoming)

Etzkowitz H, Webster A, Gebhardt C, Terra B (2000) The future of the university and the university of the future: Evolution of ivory tower to entrepreneurial paradigm. Res Policy 29:313-330

Florida R (2004) Cities and the Creative Class, Imprint Routledge, New York, NY, https://doi.org/10. 4324/9780203997673

Grable JE (2000) Financial risk tolerance and additional factors that affect risk taking in veryday money matters. J of Bus and Psychology 14(4):625-630

Granovetter M (1985) Economic Action and Social Structure: The Problem of Embeddedness, American Journal of Sociology 91(3), 481-510

Hayton JC, George G, Zahra SA (2002) National culture and entrepreneurship: a review of behavioral research. Entrep Theory and Prac 26(4):33-53

Herranz N, Krasa S, Villamil AP (2015) Entrepreneurs, risk aversion, and dynamic firms. J of Pol Econ 123(5):1133-1176

Keen CH, Etemad H (2011) Rapidly-growing firms and their main characteristics: a longitudinal study from United States, International Journal of Entrepreneurial Venturing, Volume 3, Issue 4, Fall 2011, PP 344-358

Keen CH, Etemad H (2012) Rapid-Growth and Rapid Internationalization of Smaller Enterprises from Canada, Management Decision, Volume 50, Issue 4, Spring 2012, PP. 569-590

Knight FH (1921) Risk, Uncertainty, and Profit. Houghton Mifflin, Boston, MA

Knight F (1929) and 1957, Risk, Uncertainty, and Profit, 8th edn. Kelley \& Millman, New York

Knight GA, Cavusgil ST (2004) Innovation, organizational capabilities, and the born-global firm. J Int Bus Stud 35(2):124-141. https://doi.org/10.1057/palgrave.jibs.8400071

Koellinger P, Thurik RA (2012) Entrepreneurship and the business cycle. Rev of Econ and Stat 94(4):1143-1156 
Krueger N (1993) The impact of prior entrepreneurial exposure on perceptions of new venture feasibility and desirability. Entrep Theory Pract 18:5-21

Krueger N, Carsrud A (1993) Entrepreneurial intentions: applying the theory of planned behavior. Entrep Reg Develop 5:316-323

Lazzarini SG (2015) Strategizing by the government: can industrial policy create firm-level competitive advantage? Strategic Management J 36(1):97-112

Liñan F, Fayolle A (2015) A systematic literature review on entrepreneurial intentions: citation, thematic analyses, and research agenda. Int Entrep Manag J 11:907-933

Markman GD, Baron RA (2003) Person-entrepreneurship fit: why some people are more successfulentrepreneurs than others. Hum Resour Manag Rev 13:281-301

Marquis C, Tilcsik A (2013) Imprinting: Toward a multilevel theory. Acad of Manag Annals 7(1):195-245

Mazzucato M (2013) The Entrepreneurial State: Debunking Public vs. Private Sector Myths. Anthem Press, London and New York, NY

Mazzucato M (2016) From market fixing to market-creating: A new framework for innovation policy. Ind Innov 23(2):140-156. https://doi.org/10.1080/13662716.2016.1146124

Mazzucato M (2018) Mission-oriented innovation policies: Challenges and opportunities. Ind Corp Chang 27(5):803-815. https://doi.org/10.1093/icc/dty034

McDougall PP, Oviatt BM (2000) International entrepreneurship: the intersection of two

Miller D (1983) The correlates of entrepreneurship in three types of firms. Manage Sci 29(7):770-791

Miller D, Friesen PH (1983) Strategy-making and environment: the third link. Strat Manage J

Moriano J, Gorgievski M, Laguna M, Stephan U, Zarafshani K (2012) A cross-cultural approach to understanding entrepreneurial intention. J Career Dev 39:162-185

Oviatt BM, McDougall PP (1994) Toward a theory of international new ventures. J Int Bus Stud 25(1):45-64. https://doi.org/10.1057/palgrave.jibs.8490193

Oviatt BM, McDougall PP (1995) Global start-ups: entrepreneurs on a worldwide stage. Management 9(2):30-44

Porter ME (1990) The Competitive Advantage of Nations. Free Press, New York, NY

Riedo V, Kraiczy ND, Hack A (2019) Applying person-environment fit theory to identify personality differencesbetween prospective social and commercial entrepreneurs: an explorative study. J Bus Manag 57:989-1007

Schlaegel C, Koenig M (2014) Determinants of entrepreneurial intent: a meta-analytic test and integration of competing models. Entrepr Theory Pract 38:291-332

Stenholm P, Acs ZJ, Wuebker R (2013) Exploring country-level institutional arrangements on the rate and type of entrepreneurial activity. J Bus Venturing 28(1):176-193

Stewart WH, Roth PL (2001) Risk propensity differences between entrepreneurs and managers: a metanalytic review. J Appl Psychol 86:145-153

Van Praag CM, Versloot PH (2007) What is the value of entrepreneurship? A review of recent research. Small Bus Econ 29(4):351-382. 19

Veglio, V and Romanello, R. (2021) The Covid-19 Crisis and Italian Firms: Digitalization, Internationalization, and Global Value Chain Reconfiguration, in Etemad, H. 2021, (Ed.) Small and Medium Sized Enterprises and their COVID-19 Response: Global Perspectives on Entrepreneurial Crisis Management, Edward Elgar Publishing, Nortampton, Mass. 2021 (Forthcoming)

Vergne JP, Durand R (2010) The missing link between the theory and empirics of path dependence: conceptual clarification, testability issue, and methodological implications. J Manag Stud 47(4):736-759

Welch L (1996) Information Behaviour and Internationalization. Int J Technol Manage 1(1/2):179-191

Welch L, Luostarinen R (1988) Internationalization: Evolution of a Concept. J Gen Manag 14(2):34-55

Welch L, Luostarinen R (1993) Inward-Outward Connections in Internationalization. J Int Market $1(1): 46-58$

Widén-Wulff G, Ginman M (2004) Explaining knowledge sharing in organizations through the dimensions of social capital. J Inf Sci 30(5):448-458

Publisher's note Springer Nature remains neutral with regard to jurisdictional claims in published maps and institutional affiliations. 